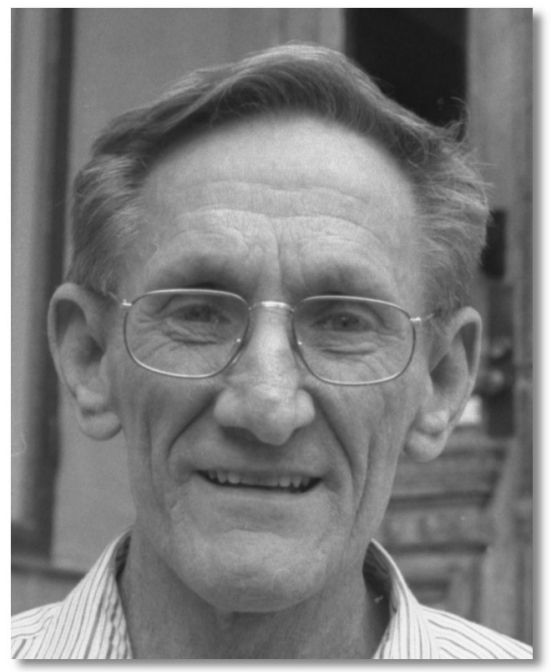

\title{
KARL-JOHAN ILLMAN IN MEMORIAM
}

Den 20 december 2002 avled en av portalfigurerna inom nordisk judaistisk, professor emeritus Karl-Johan Illman, efter en lång tids sjukdom. Han var med i Sällskapet för judaistisk forskning ända från begynnelsen och fungerade också i drygt tio år som Sällskapets ordförande. Judaister i hela Norden minns honom med tacksamhet och saknad.

Karl-Johan Illman föddes den 27 juni 1936 i Ingå, en liten landsortskommun i västra Nyland (sex-sju mil väster om Helsingfors). Han växte upp i ett jordbrukarhem och måste redan som barn på grund av allergiska svårigheter långa tider bo utanför hemmet. Enligt vad han själv berättat var han inte intresserad av lärdomsvägen men hans föräldrar satte honom i läroverk. De insåg att han var begåvad och dessutom alltför allergisk för att bli jordbrukare. Efter avlagd studentexamen sökte han sig till Finlands svenska universitet, Åbo 
Akademi. Det skulle han bli trogen ända till sin död.

Vid Åbo Akademi studerade han först vid den humanistiska fakulteten för att efter ett år byta till teologi. Han har själv berättat om hur han under studietiden var med om en livsavgörande upplevelse då han följde en uppmaning att läsa något av Martin Buber. Intresset för denna betydande judiska tänkare bevarade han livet ut, ett intresse som också resulterade i flera vetenskapliga verk.

Illman avlade teologie kandidatexamen 196r. Under 1960-talet vistades han längre perioder i Tyskland där han bedrev forskning vid universiteten i Tübingen och Münster. Sina examina avlade han dock i Åbo. Teologie licentiatexamen avlade han 1969 och sex år senare disputerade han för doktorsgraden på en avhandling om Martin Bubers bibeltolkning. I det ämnet kombinerade han de två roller han i sitt vetenskapliga arbete skulle komma att verka i: judaistens och bibelforskarens.

Judaistiken och bibelforskningen gick ofta hand i hand i Illmans arbete. Hans tre första vetenskapliga artiklar kombinerade de båda: de bar titlarna "Judisk Paulustolkning», »Anfänge der jüdischen Bibelwissenschaft» och "Judisk Jesustolkning». En person som betydde mycket för Illmans intresse för judaistik var Gösta Lindeskog, som var professor i nytestamentlig exegetik i Åbo 1964-74 och som 1965 grundade ett judaistiskt institut vid Teologiska Fakulteten. Institutum Judaicum Aboense har ett omfattande bibliotek som ofta anlitas också av utomstående.

Efter doktorsavhandlingen kom Illman att skriva några böcker med mer exegetisk inriktning. Det är fråga om Thema und Tradition in den Asaf-Psalmen (1976) och Old Testament Formulas About Death (1979). Från år 1976 skötte han den professur i gammaltestamentlig exegetik som Bertil Albrektson lämnade då han flyttade till Uppsala för att leda arbetet med den nya bibelöversättningen. Innan professuren utlystes beslöt Teologiska fakulteten att ändra dess benämning. På så sätt fick Åbo Akademi en professur i "gammaltestamentlig exegetik med judaistik». Det var den första professuren i judaistik i Norden även om ämnet bara var en del av professuren. Professuren i Lund helt tillägnad judaistik kom till senare.

Illman utnämndes till innehavare av denna professur 1980 och kom att verka i den tjänsten till sin pensionering sommaren 1999. Som professor i två ämnen skötte han sina åligganden helt och fullt, 
men hans personliga intresse och hans forskning kom nog att rätt långt ligga på judaistikens område. Han har genom året skrivit flera exegetiska arbeten, men långt fler är hans verk inom judaistiken.

Som nästan ensam lärare inom ett stort och vitt ämne har Illman varit mer eller mindre tvungen att läsa in sig på de flesta aspekter av judisk religion, kultur och historia. En klar tyngdpunkt finns dock på den moderna judendomen och som teolog har han visat speciellt intresse för judisk religion. Men framför allt kännetecknas hans judaistiska produktion av stor mångsidighet. Han har skrivit om ämnen som judisk bibeltolkning, judisk-kristna relationer, litteraturen om Förintelsen, bilden av judendom i kristen skolundervisning, judisk filosofi med mera. Själv har han i en födelsedagsintervju sagt om denna mångsidighet att »det har varit stimulerande att inte ha behövt gräva på ett ställe hela tiden.»

Illmans balanserade och sociala läggning gjorde honom väl skickad att sköta olika förtroendeuppdrag. Vid Teologiska fakulteten fungerade han både som dekanus och prodekanus. I Sällskapet för judaistisk forskning var han från början en av de centrala gestalterna. Sällskapet hade grundats som en svensk organisation 1973. Två år senare i och med den första kongressen i Stockholm förvandlades det till ett nordiskt sällskap och Illman valdes in i dess styrelse som en av representanterna för Finland. 1985 var han ordförande för den planeringskommitté som ansvarade för Sällskapets tredje kongress i Åbo. Vid denna kongress blev han också vald till ordförande för Sällskapet, en uppgift som han skötte med framgång i elva år. Under de sju första åren fanns också redaktionen för Sällskapets tidskrift, Nordisk Judaistik - Scandinavian Jewish Studies, i Åbo. Det största lasset drogs av dess redaktör, Nils Martola. Men också Illman axlade ett stort ansvar för tidskriften och var inte minst en mycket flitig skribent. För volym I3 (1992) fungerade han också som redaktör.

Både omfånget och mångsidigheten i Illmans produktion klarnar vid en granskning av innehållet i Nordisk Judaistik. Redan i tidskriftens första nummer 1975 medverkade han med en artikel: "Modern judisk bibelforskning». Hans senaste (och antagligen sista) bidrag ingick i volym 2I (2000): artikeln "What is Jewish in Jewish Philosophy?» Sammanlagt har han i Sällskapets tidskrift publicerat Io artiklar och 32 recensioner. Därtill har det 25-årsjubileumstal han höll 
på kongressen år 2000 publicerats i Nordisk Judaistik. Denna tidskrift har alltså i Illman haft en av sina aktivaste skribenter - om inte den allra aktivaste.

Illman har naturligtvis också publicerat sig i andra fora. Han har medverkat både i inhemska och internationella tidskrifter och samlingsverk. Bland annat skrev han tre artiklar i Theologisches Wörterbuch zum Alten Testament. Han gjorde också en stor insats för att föra ut de vetenskapliga rönen till en större allmänhet. Han har utgett flera populärvetenskapliga verk som funnit en stor läsekrets. Judisk historia utkom första gången 1986 och har sedan dess utkommit i inte mindre än åtta upplagor, flera av dem rejält utvidgade och reviderade. Boken används som lärobok vid flera universitet och har också översatts till finska. Också Judendomen i ljuset av dess högtider, som första gången utkom 1992, har använts som lärobok vid olika universitet. I Nationalencyklopedin medverkade han med flera artiklar i judiska ämnen.

Tillsammans med professor Tapani Harviainen från Helsingfors redigerade Illman storverket Juutalainen kulttuuri (första upplagan 1998). Boken, som utgavs av ett kommersiellt förlag och gavs ett påkostat yttre, innehåller en unik samling artiklar som sammantaget ger en god helhetsbild av mångsidigheten i den judiska kulturen. Sammanlagt tolv skribenter medverkar och Illman har själv skrivit sju artiklar i den. Tyvärr har detta verk inte hittat någon svensk förläggare, trots att merparten av materialet finns i svensk version.

Bland Illmans övriga verk kan man nämna Utmaningen - en kommentar till Jobs bok (1998), som ärkebiskop emeritus Gunnar Weman skrev en efterskrift till. Att Illman i sina exegetiska publikationer ofta behandlat Jobs bok och lidandets problematik över huvudtaget hänger nog samman med det faktum att han under nästan hela sitt liv fick kämpa med sjukdom. Till hans 60-årsdag 1996 utkom en festskrift - I Jobs tecken. Europa och judarna - innehållande artiklar av honom själv. Bland dessa finns en ypperlig översikt över antisemitismens historia. År $200 \mathrm{I}$ utkom $D u$ och den andre. Fem judiska tänkare om dialog och ansvar. Cirkeln har härmed slutits, Illman har åter en gång återvänt till Buber (de övriga är Cohen, Rosenzweig, Heschel och Lévinas). Detta är dock inte den sista boken. Det är meningen att det skall utges en bok av ett manuskript som han jobbade med, men aldrig hann slutföra. 
Inte bara som skribent utan också som föredragshållare har Illman spritt sin stora kunskap. Han kallades ofta att hålla föredrag i judaistiska ämnen. I samband med att den nya bibelöversättningen utkom 1999, en översättning som han själv bidragit till som referent och filologisk expert, var han ofta ute i församlingarna och föreläste om den. Han var ingen polemiker till sin natur, men blev tvungen att vid diskussioner och i tidningsdebatter försvara denna översättning mot dess hårdaste kritiker. Också annars deltog han gärna i samhällsdebatten och skrev debattartiklar om olika ämnen från bibeltolkning till judisk slakt.

Illman gjorde en gedigen insats också som lärare. Innan han blev professor fungerade han i många år vid Teologiska fakulteten som lärare i exegetik och de bibliska språken. Han fungerade också som docent i judaistik vid Helsingfors Universitet. Som undervisare var han utmärkt: medryckande och glasklar. Som handledare var han enastående. Otaliga gånger har jag knackat på hans dörr för att få ställa en fråga eller diskutera ett problem. Aldrig någonsin fick man intrycket att han egentligen inte hade tid med en. Tvärtom; beredvilligheten att alltid ställa upp, hjälpa till, diskutera och ge råd är en av de egenskaper som jag allra starkast förknippar med honom. Under hans tid som professor disputerade fem av hans elever. En av dem, Antti Laato, kom att efterträda honom som professor. Jag hoppas och tror att det faktum att han hade elever som haft framgångar i det akademiska livet var en källa till stor glädje för Illman.

Ett viktigt och förhoppningsvis bestående resultat av Illmans långa dagsverk vid Teologiska Fakulteten är att judaistiken här fått en respekterad och ansedd plats. Från att ha varit ett ämne som huvudsakligen fungerade som ett bihang till den gammaltestamentliga exegetiken blev den ett självständigt ämne som det var möjligt att ha som huvudämne i sin examen. Ett annat tecken på judaistikens betydelse är att den också påverkat de övriga disciplinerna: vid fakulteten har det skrivits avhandlingar inom nytestamentlig exegetik och inom patristik vilka haft judiska teman. Den kristna teologin var länge mest intresserad av judendomen som en bakgrund till den kristna tron. Att också i finländskt akademisk liv den levande judendomen blivit intressant för teologin är mycket långt Illmans förtjänst. De flesta vetenskapsmän har bidragit till sin egen disciplin. Illman bidrog till att ge den disciplin han representerade en helt ny ställning inom 
finländskt universitetsliv.

Illmans insats för judaistiken i hela Norden har alltså varit betydande. Sin installationsföreläsning den 7 november 1980 under rubriken "Judaistikens plats bland vetenskaperna» avslutade han med att deklarera sin syn på denna vetenskap och uttrycka sin optimism gällande dess framtid.

Att vetenskapligt behandla något så komplicerat och omfattande som ett folk, dess historia, kultur, religion och samhällsförhållanden låter sig naturligtvis inte göras utan specialstudier på de mest olikartade och även mycket begränsade områden. Samtidigt förutsätter benämningen judaistik ett konstant element, det judiska folket, med en historisk kontinuitet på över tre århundraden [sic]. Det är just dessa aspekter, kollektivitet och kontinuiteten, som ger judaistiken dess helhetsperspektiv och motiverar att den betraktas som ett eget fack. Hur mycket judaistik som kan få rum i forskning och undervisning, beror inte på vilket examensämne det är anslutet till, utan på hur mycket intresse det finns för just detta fack. Och här är jag optimist. (Åbo Akademis Årsskrift 64 (1979-80), 448f.)

Den optimism han här ger uttryck för vad det gäller judaistikens framtid var helt befogad. Som redan nämnts har ämnet konsoliderat sin ställning märkbart vid Illmans eget universitet. Också i Norden har utvecklingen varit positiv. Efter att detta sades har en professur inrättats i Lund, ämnet har introducerats i flera universitet och högskolor, nya framstående forskare har framträtt, intresset för ämnet har allmänt taget ökat och Sällskapet för judaistisk forskning har fortsatt en stabil verksamhet med utgivning av Nordisk Judaistik och arrangerande av kongresser.

Illman blev en mycket respekterad och omtyckt person inom Finlands judiska församlingar, i vilka han betraktades som en sann humanist och en religiös brobyggare. Han ordnade flera föredragsserier i judiska ämnen som lockade åhörare från den judiska församlingen i Åbo. En av dessa kände så stor tacksamhet över detta att han en gång sade att fakulteten blivit som ett andra hem. I sanning ett vittnesbörd att vara stolt över. 
Illman var inte den som stod på barrikaderna och högljutt drev olika frågor. Men på sitt sätt var han också en kämpande humanist. Sitt intresse och engagemang för den judisk-kristna dialogen bottnade i en övertygelse att det för fred och samförstånd i världen är viktigt med förståelse över religionsgränserna. Han innehade ingen officiell position inom den lutherska kyrka han tillhörde, men han var trots det engagerad i arbetet inom Lutherische Europäische Kommission Kirche und Judentum. I mitten av 1990-talet var han med om att grunda den finländska avdelningen av organisationen Jad Vashem, vars ordförande han var 1995-99. Jad Vashem arbetar mot antisemitism och rasism genom att lyfta fram minnet av Förintelsen.

Illman hade en mycket balanserad inställning till den israeliskpalestinska konflikten. Han kände stor sympati för Israel men hade också goda kontakter på den palestinska sidan. 1996 uttalade han sig på följande sätt: "Båda har berättigade anspråk. Man måste hitta en avvägd lösning som ger livsrum för båda folken.»

Karl-Johan Illman var sedan 1964 gift med Siv, också hon teologie doktor från Åbo (1992). De fick fyra barn. Han var en god familjefar, för vilken familjen betydde mycket. För sina insatser för det finländska samhället beviljades han 1996 riddartecknet av I klass av Finlands Vita Ros orden.

När en människa dör är det lätt att ta till överord då hennes livsverk och person skall beskrivas. Men när det gäller Karl-Johan Illman råder samstämmighet bland oss som kände honom väl att det hos honom fanns något utöver det vanliga. Kombinationen av lärdom och ödmjukhet, integritet och anspråkslöshet skapade en helgjuten och balanserad personlighet med osedvanlig resning. Han var för oss en trofast vän, en inspirerande samtalspartner och för oss i en yngre generation en naturlig fadersfigur.

Världen är bättre för att han har funnits. Världen är fattigare för att han inte längre finns. Tehi nishmato tzerurah bitzeror hachajim. 
Enligt Pirke Avot (Fädernas tänkespråk 4:6) brukade rabbi Ishmael son till rabbi Jochanan säga - "Den som studerar för att undervisa, honom skall det bliva givet att studera för att undervisa och den som studerar för att tillämpa sina studier, honom skall det bliva givet att studera, undervisa, bevara och tillämpa».

Karl-Johan Illman förkroppsligar rabbi Ishmaels lärdomar genom att han i både sin kateder och i sitt levnadssätt var ett föredöme för sina lärjungar. Till skillnad från många kallsinniga vetenskapsmän, vilkas studiefält var helt skilt från deras leverne, var »Kalle» en professor och vetenskapsman, som levde som han lärde. Han var bland mycket annat en Buberist och han tog Bubers "Jag och du»-problematik på allvar. Han tog sig tid för alla människor, och han ställde sig till förfogande för föredrag och rådgivning om den judisk-kristna dialogen. Han hjälpte oss i Sverige och arbetade i Finland mot en oövervinnelig likgiltighet. Dialogen i Finland har inte haft någon framgång, men det är inte Karl-Johan Illman skyldig till. Han försökte med sina böcker, sin undervisning och sin närvaro. Professor Illman var en välkommen gäst vid Finlands Judiska församling i Helsingfors och Åbo.

Vår personkemi fungerade och vårt samarbete berikade mitt liv. Jag skrev några artiklar om judisk historia och religion för publicering, höll ett fătal föredrag i Finland, beställde en del böcker för mina studiecirklar, konsulterade honom om svåra bibeltexter (vi arbetade båda med Bibel 2000) och jag rådgjorde med honom i dialogfrågor. Detta mångfacetterade samarbete hade en positiv effekt på min rabbinska karriär - långt över dess omfång. Professor Karl-Johan Illman var en av de ganska få personer i Norden som lyfte mig över pressande församlingsangelägenheter, som annars lätt kunde växa att bli allomfattande och kullkasta mina möjligheter till djupare studier och forskning. Jag är oerhört tacknämlig för att detta inte skedde.

Karl-Johan Illman studerade för att tillämpa sina studier. Ja, han gjorde mer än så. Han lärde andra att tillämpa sina studier. I detta var han en kristen, som förkroppsligade ett av den rabbinska judendomens mest centrala ideal. 